\title{
Diffusion trends and Nahuatlisms of American Spanish: Evidence from dialectal vocabularies
}

\author{
María-Teresa Cáceres-Lorenzo
}

\begin{abstract}
Missionary linguistics and considerations of Nahuatl as a lingua franca lead us to propose that Nahuatlisms have historically been prominent in American Spanish. Diachronic studies show that after Spanish spelling was standardised, involving occasional losses and extensions of meaning, Aztec words were incorporated into Spanish language vocabularies in the Americas. Because $16^{\text {th }}$ and $17^{\text {th }}$-century data provide inconsistent depictions of the spread of Nahuatlisms in the Caribbean and in South American regions, our research aims to collect data from American Spanish dialectal vocabularies to reconstruct regionalisation and diffusion trends of $\mathrm{Na}$ huatlisms in the centuries that followed. Utilising quantitative and qualitative methodologies, we design a research study that identifies restricted and regional characteristics of more than $84 \%$ of Nahuatlisms and of remnants of Nahuatl words in the Caribbean and in South American regions.
\end{abstract}

\section{Introduction}

Studying American Spanish dialectal vocabulary is one means of analysing the continuity of indigenous words in the Americas (Ávila 2004). The spread of Nahuatl names and meanings in the Spanish language followed a specific pattern from the $15^{\text {th }}$ century onwards, which we examine using lexicographical material. This diffusion trend follows processes of acculturation, regionalisation, diffusion, transformation and enrichment (Sánchez-Albornoz 2001). Indeed, according to the Diccionario de la Real Academia Española [Dictionary of the Spanish Language] (DRAE 2014), 523 registered Nahuatl words are present in the Panhispanic Spanish language, representing 38\% of all Indoamericanisms in the Spanish language.

The majority of Hispanists argue that Nahuatl words first appeared in Spanish colonial texts in 1519 in the first writings of Hernán Cortés and other chronicler-soldiers (Lope Blanch 1998; Enguita Utrilla 2004). This early use of Nahuatl words by Spanish writers does not imply that such words functioned as everyday vocabulary in American Spanish. Rather, Nahuatlisms in Spanish texts were included for propaganda purposes. In other words, these registered words were not necessarily broadly accepted in the Spanish language (Schäffner 2012). In this study, we are thus interested in the actual 
utilisation of indigenisms as dialectal vocabulary for communication in the Americas.

Given the importance of Nahuatl from religious, economic and socio-cultural perspectives, we find a trend of Nahuatl vocabulary expansion in the Spanish language. This trend is not exclusive to the Mesoamerican region but a priori involves other areas such as the Caribbean and South American regions (Zavala 1996). In this study, we aim at identifying historical trends using dialectal vocabulary data from these regions.

Previous studies on the history of the Spanish language identify an information gap on the spread of Nahuatlisms after the colonial period $\left(18^{\text {th }}-20^{\text {th }}\right.$ centuries), and we strive to fill this gap through the study of dialectal vocabulary. The method of using dialectal words as material for historical language reconstruction has previously been applied by other researchers due to the conservative nature of this vocabulary and its leaning towards the archaic (Alvar Ezquerra 1986). It is common for this dialectal vocabulary repertoire to be absent from large word inventories of standard Spanish currently used. The same trend has occurred in the case of Nahuatlisms in the Americas, which are occasionally deemed to be words on the verge of extinction or words of significant colloquial reach at the level of oral communication (Oesterreicher 2002).

A Nahuatlism in the Spanish language can be defined as a word exhibiting a high level of regionalisation and a low index of generalisation. We define the term regionalisation as the differential use of an indigenous word within a particular territory. The generalisation or diffusion index refers to the numerical expression of the ratio between these words and the American countries where they are used. In the first centuries of its existence, the American Spanish language already presented unique configurative elements in a diasystem of fundamentally diatopic varieties which produced, in all certainty, diastratic and diaphasic consequences (Frago Gracia 1999; Tabernero Sala 2011).

Following this line of research, studies by Lope Blanch (1993) show that the possible survival of Aztec vocabulary in Mexico City can be viewed as a double or triple process of regionalisation. That is, this vocabulary is even more restricted because many words are only used in Mexico. However, these words have also undergone a process of levelling due to extralinguistic and linguistic characteristics of dialectal words used in urban areas:

En efecto, en el habla total de la ciudad de México, con sus casi 18 millones de habitantes de todas clases y condiciones, sólo tienen cabida poco más de 300 vocablos - correspondientes a 237 lexemas-, algunos de ellos de uso muy restringido, de manera que no llegan siquiera a 200 voces - procedentes de sólo 166 lexemas amerindios - las que se co- 
nocen y usan en el habla urbana de México. Y, lo que es aún más revelador, la vitalidad de esos 300 vocablos, su índice de aparición en la cadena hablada o escrita, 40, apenas alcanza el 0,09\% de la muestra total. (Lope Blanch 1993: 330)

Indeed, the total vocabulary of Mexico City, with a population close to 18 million that includes all socioeconomic classes, only includes approximately 300 words corresponding to 237 lexemes (some of which are used very rarely, thus reaching no more than 200 words), which derive from as few as 166 Amerindian lexemes that are known and used in the urban speech of Mexico City. What is even more revealing is the vitality of these 300 words. Their rate of occurrence in the spoken or written chain is 40 , accounting for only $0.09 \%$ of the total sample.

Returning to historical data, the first recorded data on this subject indicate the presence of Nahuatl vocabulary during the $16^{\text {th }}$ century as the vocabulary of a general language that was expanding rapidly due to its status as a lingua franca (Terborg et al. 2006; Schwaller 2012). This diffusion was limited to the geographical boundaries of the Aztec empire:

No hemos hallado voces nahuas en la zona del Mar del Caribe. Podemos afirmar, entonces, que los tainismos, como hemos demostrado [...] siguieron la ruta de los conquistadores; pero no los nahuatlismos, que escasamente pasaron a Tierra Firme y al Nuevo Reino de Granada, siendo su influencia nula en el cono sur durante el siglo XVII. (Mejías 1980: 31)

We have not found Nahuatl words in the Caribbean Sea area. We can thus state that Tainisms, as we have demonstrated [...] followed the route of the conquistadors; but this did not happen with Nahuatlisms, which barely passed to the mainland and to the New Kingdom of Granada, and which had no influence in the southern cone during the $17^{\text {th }}$ century.

Regionalisation during this initial period depended on two extralinguistic issues that influenced the adoption of indigenous vocabulary. First, the Spanish language had received lexical Tainisms as necessary words of American Spanish. That is, written texts in Spanish already frequently used indigenous Antillean words. ${ }^{1}$ Second, South American populations already possessed

${ }^{1}$ López Morales (1974) notes the generalisation indices of the following Antillean lexias: achote, areito, batata, batey, bejuco, bohio, cacique, canoa, caribe, cazabe, ceiba, cemí, guayacán, hamaca, huracán, maíz, piragua, yagua, yuca, úcar, and the Nahuatl word cacao. Lope Blanch (1999) points to the existence of general Americanism use in the Diccionario de Alonso de Molina castellano-Nahuatl (1571): aji, batata, batey, bohio, canoa, coa, cutaras, embijar, maguey, maíz and tuna (Castilian-Nahuatl); and aguachil, cacao, capulín, mecapal, petaca and tameme (Castilian-Nahuatl). Meanwhile, Cáceres Lorenzo 
Quechuan vocabulary-another lingua franca. This limited the use of Nahuatlisms.

Despite the above conditions, we find documented evidence of a certain degree of generalisation in colonial texts, and we show that they are not always subjected to the aforementioned Mesoamerican territorial limitations in the use of Nahuatlisms. Aztec words were also used in various South American countries, illustrating new American characteristics of the Spanish language in similar ways as Antillean vocabularies of the Caribbean islands (Lope Blanch 1998). To corroborate the use of Nahuatlisms in the southern region, we cite a study by Bravo García and Cáceres Lorenzo (2013) on descriptive texts from the Americas. This study examines the case of distinct names designated to the Persea Americana. These words included curagua (the lexia of Venezuela and Chile), curo (a Colombian word), palta (Quechism) and aguacate (Nahuatl). Authors from the southern regions of the Americas during the $16^{\text {th }}$ century preferred the latter three naming schemes in the following order: Nahuatl, Quechua and Caribbean naming. These same South American reports also demonstrate that aguacate is a Spanish word; i.e., it was an incorporated word: "suelen sembrar y criar unos árboles altos que llaman curagua y los españoles aguacate", [they often plant and nurture a type of tall tree that they refer to as curagua, while the Spanish use the word aguacate] [1558]. (Bravo García \& Cáceres Lorenzo 2013: 119)

To understand the use of Nahuatlisms in non-Mesoamerican contexts, it is worth remembering that Spanish dialects that reached the Americas were used by speakers imbued in an evidence culture. ${ }^{2}$ Within knowledge schemes of Renaissance Hispanic culture, the appearance of lexical indigenisms was related not only to communication needs but also to the need to exhibit expert knowledge of Indigenous vocabulary. While this system was supported by Spaniards living in European and American territories, it was also present among indigenous communities. Lockhart (1999: 11) describes the cultural value of Nahuatl words shared by different indigenous peoples in Mesoamerican administrative divisions. Spaniards were thus aware of the socio-cultural value of Nahuatlisms.

The core issue that we examine is based on the possible theoretical divergence about the diffusion of dialectal Nahuatlisms in the Spanish language:

(2013) illustrates the general diffusion of aji, barbacoa, batata, bejuco, canoa, ceiba, hamaca and manatí.

${ }^{2}$ By this concept, we mean the culture originating from some official or personal documents from colonial America. The social value of this practice, according to Goodwin (2007: 150), "was the written element in an administrative mechanism that enabled individuals to petition the crown requesting personal favor (merced), usually either a pension or an official post". 
what does the dialectal vocabulary illustrate in terms of regionalisation or the generalisation Nahuatlism indices? This general question allows us to ask the following: is it possible to identify a trend in $16^{\text {th }}$ - and $17^{\text {th }}$-century texts in which dialectal and differential bodies of modern American Spanish are present?; what is the geographical tendency of Nahuatl word-use according to current data on dialectal vocabulary?; and, which lexical areas possess the majority of these terms?

The results of this study will prove useful in ascertaining diachronic and diatopic aspects of Nahuatl words that functioned as possible loanwords in the configuration of American Spanish. This assessment provides comparative research on acculturation and meanings derived from a communicative level, which can be used in future studies.

\section{Theoretical framework}

In answering the proposed research questions, we construct a working hypothesis based on the following theoretical premises:

\subsection{Dialectal words allow for the diachronic reconstruction of Nahuatl vo- cabulary}

The relationship between dialectal or differential vocabularies and the historical reconstruction of determined vocabularies has been examined on various occasions (Hernández 1996; Frago Gracia 1999; Company 2003). Conclusions from these studies suggest that results obtained from dialectal bodies contain words that were used over different diachronic phases (García Mouton 1996).

Examples of what we propose can be found in the words aji/chile [chili], batata/camote [sweet potato], and maizal/milpa [maiz]. These Caribbean/Nahuatl name pairs constantly competed for the same meaning throughout the so-called Spanish Golden Age. Currently, these words are listed under different generalisation or diffusion indices in the Diccionario de Americanismos (DA 2010). In addition, the words canoa/acal [canoe] competed throughout the first colonial centuries. Sebastián de Covarrubias explained this trend in his 1611 work, Tesoro de la lengua castellana o española [The Thesaurus of the Spanish or Castilian Language]:

Es nombre compuesto de atl, que vale agua, y calli, casa, y todo junto casas de agua. Esto es en lengua mejicana; mas porque las tales barquillas las llaman en Santo Domingo, donde primero estuvieron los españoles, canoas, las llamaron a todas deste nombre [This name is composed of the words atl, which means water, and calli, which means home, and together, these words create the term 'water homes'. This is the Mexican language; however, in Santo Domingo, where the Spanish 
first landed, because pods are called canoas, all boats were given this name]. (Covarrubias 2006: s.v. canoa)

Prior to this statement, Franciscan friar Bernardino de Sahagún, a great collector of Nahuatl words, stated in the Spanish section of his Historia General de las cosas de Nueva España [General History of New Spain] that he prefers canoa to the Nahuatl word (Bastardín Candón 2013: 94). Perhaps due to this naming complication, there is no dialectal and differential word for acal in the DA (2010). This expansion trend demonstrates the tendency to favour Caribbean word-use over Nahuatlisms in the Americas.

Previous research has found that, according to historical data, several lexical indigenisms in American Spanish belong to dialectal and rural vocabularies (Bastardín Candón 2013). Scholars highlight that Indians largely lived in rural areas; thus, their presence in Spanish-founded cities was minimal (Sánchez Méndez 2010).

The Indian "republics" (a categorisation that fuses the Indian heritage with the conquerors' Christianity and their intentions to fully dominate the conquered peoples) did not fully adopt the Castilian variety of Spanish until either the end of the $16^{\text {th }}$ century or the beginning of $17^{\text {th }}$ century. It is thus not surprising that a large body of indigenous words were better preserved in these rural areas. The use of prehispanic words of different origins outside their original territories was strengthened by various factors: i) many words were lost, and thus, they do not appear in current dialectal bodies (López Morales 1974); ii) indigenisms usually survived in dialectal form; and, iii) the meanings of native words were modified when added to the Spanish language (Frago Gracia 2003). Over time, speaker-facilitated, lexical-levelling processes resolved possible coincidences while also leading to the acceptance of some loans for the purpose of effective communication (Enguita Utrilla 2009; Tabernero Sala 2011; Bravo García and Cáceres Lorenzo 2013).

Although dialectal vocabularies are also sought in large cities such as Mexico City, the data suggest a very small degree of use in these areas (Lope Blanch 1993). The registering of dialectal words allows for the recognition of historical trends of Nahuatl inclusion into Spanish.

\subsection{The regionalisation and generalisation index of Nahuatl words depends on extralinguistic factors}

The decision to use Nahuatl as a general language was promoted primarily by the Franciscans. These friars used Nahuatl systematically in their missionary work through the production of multiple publications aimed at teaching Nahuatl to other Spanish missionaries (León Portilla 1999). Hispanicisation 
delayed missionary work (Ricard 2001), thus leading to the creation of missionary vocabulary works that were viewed as necessary to evangelisation. In the words of Klor de Alva:

The missionaries appropriated the authority already encoded in the discursive practices of the nobility. This they accomplished by translating the literature necessary for the Christianization process using the rhetorical moves and vocabulary of the newly alphabetized Classical Nahuatl. The ritual, by which the leaders had long helped to shape the ideology of the masses of commoners, became both the language of instruction about the ways of the Europeans and the language by which the ideological speech of the native leader-ship was domesticated to serve the ends of colonial discourse. (Klor de Alva 1989: 147)

However, the creation of missionary linguistics did not directly result in the adoption of Nahuatlisms into Spanish during this period. Not all indigenous words were collected either. A selection process was followed for the development of collection questionnaires that were based on an entirely Eurocentric perspective. ${ }^{3}$ In fact, in both New Spain and the Inca territory, the clergy feared indigenous words because they "conceptualized the inseparability of native languages and profane beliefs in hereditary terms, believing that false religion passed from one family generation to the next by way of language" (Charles 2007: 27).

At the same time, Spaniards illogically accepted that Nahuatl should be the common language. This issue was accepted by the Crown based on the linguistic diversity of the Americas (which was much more evident in South America) and on the need to communicate for evangelisation purposes. After all, Nahuatl had been used as a communicative language in Mesoamerican territory since the prehispanic period. The decision to establish university faculties dedicated to the study of the most common indigenous languages by friars and priests is, thus, a product of this feature. It is difficult to find examples of colonisation processes in which the invader learns the language of the conquered, unless this was done for religious purposes (Pizzigoni

\footnotetext{
${ }^{3}$ E.g., in methodologies used by the Franciscans of New Spain, the observance of European traditions while collecting indigenous knowledge is evident. This is described by Alfredo López-Austin (1974: 120) as "se origina en los estudios zoológicos griegos, pasa por las historias naturales latinas y llega al Nuevo Mundo en la forma de enciclopedias medievales en las que se recogen todos los seres en un riguroso orden jerárquico, empezando por la Trinidad y terminando con los minerales" [originating in Greek zoological studies, passing through Latin natural history and reaching the New World in the form of a medieval encyclopaedia where all beings are brought together under a rigorous and hierarchical order, which begins with the Trinity and ends with minerals].
} 
2012). This trend ultimately subjected Nahuatlisms to a process of orthographic standardisation and occasional cases of semantic change (Hernández 1996). While this enabled the diffusion of words, it also facilitated acculturation processes when certain forms and meanings were favoured over others (Rodríguez Reboiras 2010).

Bilingualism existed on various levels: members of the clergy based their missionary work on a thorough knowledge of Nahuatl, as it was believed that evangelising in Nahuatl was necessary to fulfil the Crown's mandate (Solano 1992); on another level, we find the existence of Indians or mixed-race Ladinos who served as communication bridges between the two republics during commercial and social interactions (Looze 2005); and, finally, writers such as friars and officials who used Nahuatl words for taxonomic and ethnographic purposes (Enguita Utrilla 2004; Bastardín Candón 2013).

\subsection{The trend of Nahuatlism diffusion during the $16^{\text {th }}$ and $17^{\text {th }}$ centuries}

The relationship between Spanish and Nahuatl words first formed in 1519, when the conquistadors reached Tenochtitlan (León Portilla 1999). Chronicled texts written by soldiers under the command of Hernán Cortés (14851547) and Juan Díaz (1480-1549) several months after the conquest illustrate the linguistic and socio-cultural mechanisms of the inclusion of Nahuatl indigenism inclusion (acal [water], cacao [cocoa], cacle [sandal] and escaupil [cotton shirt]) into Spanish, despite the fact that these words had not necessarily been incorporated into the language at that time. In the first Spanish texts written during the $16^{\text {th }}$ and $17^{\text {th }}$ centuries in this region, we find a discursive strategy that involves presenting autochthonous words as exotic indicators of a new communication context to be used by Europeans (Binnoti 1992). This strategy involved the selection of historical indicators by authors of Hispanic texts when confronted with Nahuatl words, and we attempt here to reconstruct this process in reference to dialectal vocabularies of the Americas.

American Spanish did not always include Nahuatlisms. In fact, during the $17^{\text {th }}$ century, we find a negative attitude towards indigenous loanwords and a linguistic loyalty to written Spanish among Spaniards and Creoles (Mejías 1980). Despite this tendency, the same scholar notes that contributions made by Nahuatl were highly significant in numerical terms to Spanish colonial texts. Data extracted by Zamora Munné (2002: 98) from $16^{\text {th }}$-century texts shows that the most common Prehispanisms are Nahuatl words $(41.25 \%)$ and Tainisms (30\%). Mejías (1980: Table 3) provides similar Nahuatl and Taino data for the $17^{\text {th }}$ century. More recently, Cáceres Lorenzo (2013: 1084) presented references to documents (1502-1560) that lead us to believe that 46 words were widely used in three colonial areas (the Caribbean, Mesoamerica 
and South America). Only eight Nahuatl words were found: cacaguate [peanut]; cacao [cocoa]; calachuni [Indian chief]; macegual [commoner]; petaca [suitcase made from reeds]; tameme [human porter]; tepuzque [copper]; and, tiangue [market]. The same trend did not occur in the case of Antilleanisms, which have always been widely used in Spanish.

\section{Materials and methods}

The study we have designed employs both quantitative and qualitative methods, which were applied to a dialectal body of data extracted from the Diccionario de Americanismos [Dictionary of Americanisms] (DA 2010), which was published by the Spanish Language Academies Association (ASALE, in Spanish). This academic work is a dictionary of descriptive, usage and differential information that was selected due to its inclusion of all studies conducted on the differential vocabularies of American Spanish. We performed the following research tasks:

1) We first compiled all Nahuatl words included in the DA. After creating this lexicon and recording the data into a spreadsheet, we were able to classify the data according to diatopic categories offered by the DA. This produced various sub-bodies in which geographical information was related to a given Nahuatlism. Our research considered the following linguistic areas in terms of prehispanic vocabularies:

- Mesoamerica, which is influenced by Nahuatl and includes: Costa Rica; El Salvador; Guatemala; Honduras; Mexico; and Nicaragua. This area was not affected by political linguistics or the socio-cultural acceptance of indigenous loanwords used by Spaniards in their writings. Even prior to the conquest, Nahuatl had become the lingua franca due to economic and political actions by the Aztecs.

- The Caribbean: Colombia; Cuba; Panama; Puerto Rico; Dominican Republic; and Venezuela. Populations in this geographical area have used indigenous Taino words that have been incorporated into the Spanish language since 1492. Nahuatl words competed with these loanwords. Additionally, Antillean vocabularies were incorporated and adopted widely in the other two areas.

- South America is referred to as the region in which autochthonous words were highly heterogeneous: Argentina; Bolivia; Chile; Ecuador; Paraguay; Peru; and Uruguay. This area possesses its own general language and thus receives loanwords from other areas that conflict with established dialectal vocabularies. 
2) We then conducted a signified-signifier comparative analysis to obtain information on possible variations in meaning changes. During this phase, we studied relationships between signified and Nahuatl words that are recognised in certain areas.

3) Finally, we parsed out Nahuatl names and coinciding meanings for various areas. For the purposes of this study, we associate the variable number of countries with our analysis of widespread Nahuatlisms.

\section{Results and discussion}

A total of 1,454 words in the dialectal vocabulary were found to contain $\mathrm{Na}$ huatlisms. Please note that the DRAE 2001 includes 473 Nahuatl words for Panhispanic Spanish. The geographical distribution is shown in Figure 1.

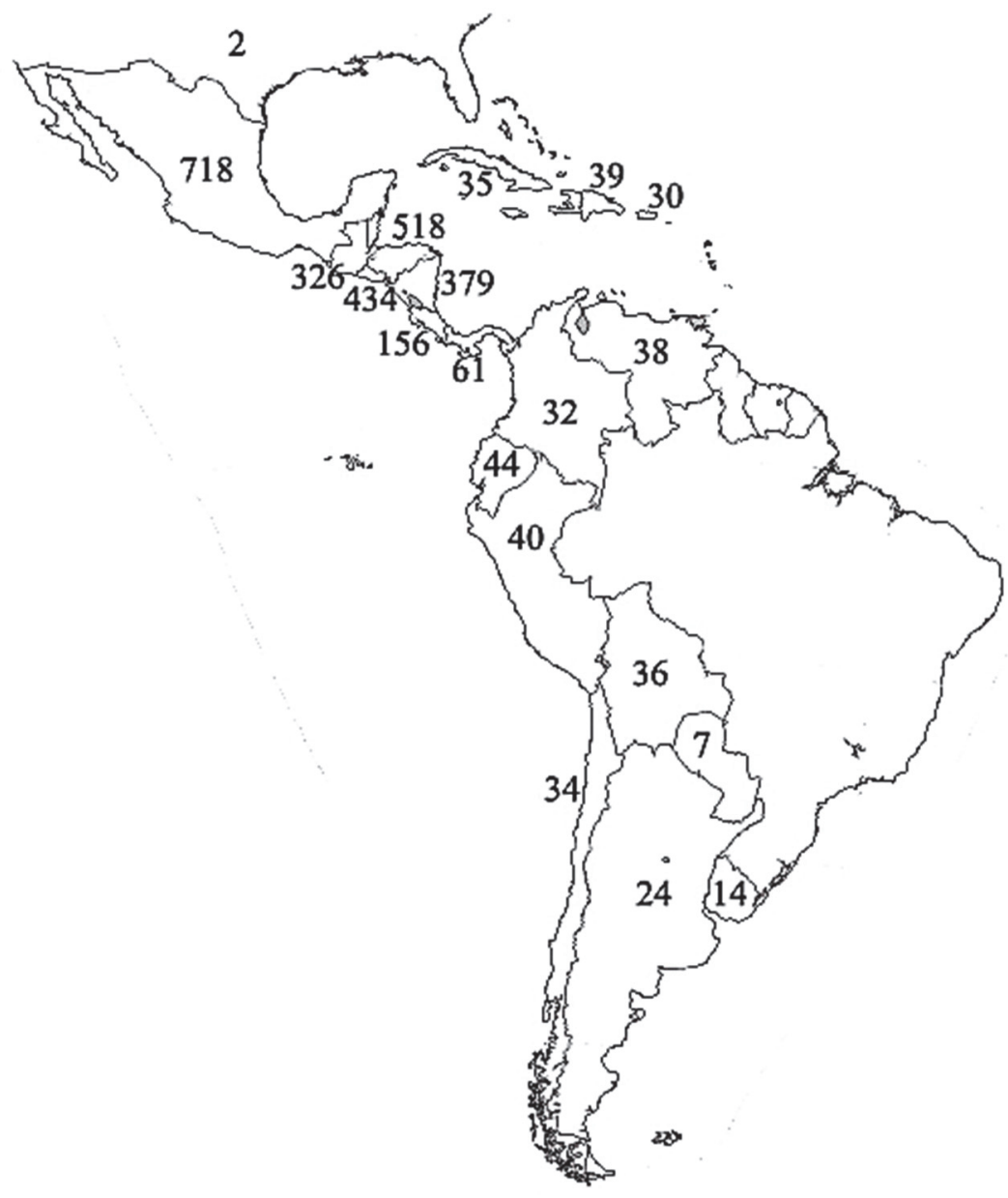

Fig. 1. Number of Nahuatlisms in the dialectal vocabularies of spoken Spanish for each country 
A total of $84.5 \%(1,228)$ of these words are found exclusively in the Mesoamerican region (Mexico, Guatemala, Honduras, El Salvador, Nicaragua and Costa Rica). The other two American regions, the Caribbean and South America, account for $15.5 \%$ of the words (226 Nahuatlisms). These figures show an enormous difference between the territories, distinguishing between countries where Nahuatl is the native language (Mexico, El Salvador, Honduras, Guatemala and Nicaragua) and neighbouring Central American areas where the data show a significant decline (Costa Rica and Panama). In the rest of the countries studied, the number of dialectal terms ranges between 24 in Argentina and 44 in Ecuador, with the exception of Paraguay and the United States, which both possess fewer than 10 words each.

The 1,454 Nahuatlisms of American Spanish are distributed as follows: 1,331 cases are found in just one region, 90 are found in two regions, and 33 have been adopted in three regions. The three linguistic areas (the Caribbean, Mesoamerica and South America) thus possess Nahuatl words. As is shown in Table 1, the Caribbean and South America share the highest number of words.

We make the following observations based on this lexical inventory:

i) Thirty-four per cent of the words refer to nature. These words are more widely used (achiote; aguacate; camalote; camote; ocelote; and zapote are used in over 10 countries) than the rest, which are not as common (jicama; mapache; and nopal).

ii) Names of traits represent $24 \%$ of the words. These Nahuatlisms possess various diffusion levels. Medium-popularity terms are present: chueco, which possesses four meanings: chicle; colocho; petaca and otomía (the last of these is not registered in Mexico).

iii) Utensils and objects compose $18 \%$ of the words (chicote; champa; chapapote; copal; guacal; mecate; and petaca). Finally, both food (moderately popular: tamal; guacamole; cajeta; atol) and family naming terms (nana; chamaco and cuate) comprise $12 \%$ of the words.

In determining the degree of Nahuatl vocabulary diffusion for each of the countries analysed, we have created an index that compares the total number of Nahuatl terms found in each country to the number of words possessing the localisation value held by the 33 most common examples, which are present in the three American areas that we consider. This index is shown in Table 2 . 
Table 1. Common Nahuatlisms in Mesoamerica, the Caribbean and South America $(\mathrm{M}=$ Mexico; $\mathrm{ES}=\mathrm{El}$ Salvador; $\mathrm{N}=$ Nicaragua; $\mathrm{G}=$ Guatemala; $\mathrm{H}=$ Honduras; $\mathrm{CR}=$ Costa Rica; $\mathrm{Pa}=$ Panama; $\mathrm{PR}=$ Puerto Rico; $\mathrm{RD}=$ Dominican Republic; $\mathrm{Cu}=\mathrm{Cuba}$; $=$ Venezuela; $\mathrm{C}=$ Colombia; $\mathrm{P}=$ Peru; $\mathrm{A}=$ Argentina; $\mathrm{E}=$ Ecuador; $\mathrm{Py}=$ Paraguay; $\mathrm{B}=\mathrm{Bo}-$ livia; $\mathrm{U}=$ Uruguay; $\mathrm{Ch}=\mathrm{Chile}$ )

\begin{tabular}{|c|c|c|c|c|c|c|c|c|c|c|c|c|c|c|c|c|c|}
\hline \multirow{2}{*}{ Words and meanings } & \multicolumn{5}{|c|}{ MESOAMERICA } & \multicolumn{6}{|c|}{ CARIBBEAN } & \multicolumn{6}{|c|}{ SOUTH AMERICA } \\
\hline & $\mathrm{M}$ & ES & \begin{tabular}{l|l}
$\mathrm{N}$ & $\mathrm{C}$ \\
\end{tabular} & \begin{tabular}{l|l}
$\mathrm{G}$ & $\mathrm{H}$ \\
\end{tabular} & CR & $\mathrm{Pa}$ & PR & $\mathrm{RD}$ & $\mathrm{Cu}$ & $\mathrm{V}$ & C & & \begin{tabular}{l|l}
$\mathrm{A}$ & $\mathrm{E}$ \\
$\mathrm{n}$
\end{tabular} & \begin{tabular}{l|l|} 
E & Py \\
\end{tabular} & \begin{tabular}{|l|l|}
$y$ & $B$ \\
\end{tabular} & $\mathrm{U}$ & $\mathrm{Ch}$ \\
\hline achiote tree, f & 1 & 1 & \begin{tabular}{l|l}
1 & 1 \\
\end{tabular} & \begin{tabular}{l|l}
1 & 1 \\
\end{tabular} & & 1 & & & 1 & 1 & 1 & 1 & \begin{tabular}{l|l}
0 & 0 \\
\end{tabular} & \begin{tabular}{l|l}
0 & 0 \\
\end{tabular} & \begin{tabular}{l|l|}
0 & 1 \\
\end{tabular} & 0 & 0 \\
\hline $\mathrm{ach}_{1}$ & & 1 & 1 & 1 & & 1 & & & 1 & 1 & 1 & 0 & \begin{tabular}{l|l}
0 & 0 \\
\end{tabular} & 0 & 1 & 0 & 0 \\
\hline aguacate 't & & 1 & 1 & 1 & & 1 & & & 1 & 1 & 0 & 0 & \begin{tabular}{l|l}
0 & 0 \\
\end{tabular} & 0 & 0 & 0 & 0 \\
\hline atol & 0 & $\underline{0}$ & 1 & 1 & & 0 & & & & 1 & 0 & 0 & \begin{tabular}{l|l}
0 & 0 \\
\end{tabular} & 0 & 0 & 0 & \\
\hline caj & 1 & 0 & 0 & 1 & & & & & 0 & 0 & 0 & 1 & \begin{tabular}{l|l}
0 & 1 \\
\end{tabular} & 0 & 0 & 0 & 0 \\
\hline cama & 1 & 1 & 1 & 1 & 0 & 0 & 0 & & 1 & 0 & 0 & 0 & \begin{tabular}{l|l}
1 & 1 \\
\end{tabular} & 0 & 1 & 1 & 0 \\
\hline cam & & 1 & 1 & 1 & 1 & 1 & 0 & ( & 0 & 1 & 0 & 1 & $1 \mid 1$ & 1 & 1 & 0 & 1 \\
\hline camote 'tu & 1 & 1 & 1 & 1 & 1 & 1 & ( & & 0 & 1 & \begin{tabular}{|l|l}
0 & \\
\end{tabular} & 1 & \begin{tabular}{l|l}
1 & 1 \\
\end{tabular} & 1 & 1 & 0 & 1 \\
\hline aco & 1 & 1 & 0 & \begin{tabular}{l|l}
1 & 1 \\
\end{tabular} & & $\underline{0}$ & & & 1 & 0 & 0 & 1 & \begin{tabular}{l|l}
0 & 0 \\
\end{tabular} & 0 & 0 & 0 & 0 \\
\hline champa : & 1 & $\underline{0}$ & 1 & \begin{tabular}{l|l}
0 & 1 \\
\end{tabular} & & 1 & 0 & & 0 & 0 & 0 & 0 & \begin{tabular}{l|l}
0 & 0 \\
\end{tabular} & 0 & 0 & 0 & 1 \\
\hline chapapote 'a & 1 & 0 & 0 & \begin{tabular}{l|l}
0 & 0 \\
\end{tabular} & 0 & 0 & 0 & & 1 & 1 & 0 & 0 & \begin{tabular}{l|l}
0 & 0 \\
\end{tabular} & 0 & 0 & 0 & 1 \\
\hline chic & 1 & 1 & 0 & \begin{tabular}{l|l}
1 & 1 \\
\end{tabular} & 1 & 1 & 0 & 1 & 1 & 1 & 1 & 1 & \begin{tabular}{l|l}
0 & 1 \\
\end{tabular} & 0 & 1 & 1 & 0 \\
\hline chicote $\mathrm{v}$ & 1 & 1 & 1 & 1 & 0 & 1 & 1 & 1 & 1 & 1 & 0 & 1 & \begin{tabular}{l|l}
1 & 1 \\
\end{tabular} & 1 & 1 & 1 & 1 \\
\hline chueco ${ }^{\circ}$ & 1 & 0 & 1 & \begin{tabular}{l|l}
0 & 1 \\
\end{tabular} & & 1 & $c$ & & 0 & 0 & 1 & 0 & \begin{tabular}{l|l}
0 & 1 \\
\end{tabular} & 0 & 1 & 0 & 0 \\
\hline chus & 1 & 1 & 0 & \begin{tabular}{l|l}
1 & 0 \\
\end{tabular} & & 1 & 0 & & 0 & 1 & 1 & 1 & \begin{tabular}{l|l}
1 & 1 \\
\end{tabular} & 1 & 1 & 1 & 0 \\
\hline chu & 0 & 0 & 0 & \begin{tabular}{l|l}
0 & 0 \\
\end{tabular} & 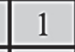 & 0 & 0 & 1 & 0 & 0 & 0 & 0 & \begin{tabular}{l|l}
1 & 0 \\
\end{tabular} & 0 & 0 & 0 & 0 \\
\hline & 1 & 1 & 1 & \begin{tabular}{l|l}
1 & 1 \\
\end{tabular} & 1 & 1 & 0 & & 1 & 1 & 1 & 1 & \begin{tabular}{l|l}
1 & 1 \\
\end{tabular} & 0 & 1 & 1 & 1 \\
\hline colo & 0 & 1 & 1 & 0 & & 1 & 0 & 0 & 0 & 0 & 0 & 1 & \begin{tabular}{l|l}
0 & 0 \\
\end{tabular} & 0 & 0 & 0 & 1 \\
\hline copal ${ }^{\prime}$ & 1 & 1 & 1 & 1 & 0 & 0 & 0 & 0 & 0 & 0 & 1 & 0 & \begin{tabular}{l|l}
0 & 0 \\
\end{tabular} & 0 & 1 & 0 & 0 \\
\hline cuate & 1 & 0 & 1 & 1 & $\underline{0}$ & 0 & 1 & 0 & 0 & 1 & 0 & 0 & \begin{tabular}{l|l}
0 & 0 \\
\end{tabular} & 0 & 1 & 0 & 0 \\
\hline guacal 'c & 1 & 0 & 0 & \begin{tabular}{l|l}
0 & 0 \\
\end{tabular} & 0 & 0 & 0 & 1 & 1 & 1 & 1 & 0 & \begin{tabular}{l|l}
0 & 1 \\
\end{tabular} & 0 & 0 & 0 & 0 \\
\hline guace & 1 & 0 & 0 & \begin{tabular}{l|l}
0 & 0 \\
\end{tabular} & & 1 & 1 & 0 & 0 & 0 & 1 & 1 & \begin{tabular}{l|l}
0 & 1 \\
\end{tabular} & 1 & 0 & 0 & 1 \\
\hline jícan & 1 & 0 & 1 & \begin{tabular}{l|l}
1 & 0
\end{tabular} & 0 & 0 & 0 & 1 & 0 & 0 & 0 & 0 & \begin{tabular}{l|l}
0 & 1 \\
\end{tabular} & 0 & 0 & 0 & 0 \\
\hline mapache & 1 & 1 & 1 & \begin{tabular}{l|l}
1 & 1 \\
\end{tabular} & 1 & 0 & 0 & 0 & 0 & 0 & 1 & 0 & \begin{tabular}{l|l}
0 & 1 \\
\end{tabular} & 0 & 0 & 0 & 0 \\
\hline mecate 'rope' & 1 & 1 & 1 & 1 & 1 & 1 & 0 & 0 & 0 & 1 & 1 & 0 & \begin{tabular}{l|l}
0 & 1 \\
\end{tabular} & 0 & 0 & 0 & 0 \\
\hline nana 'ba & 1 & 1 & 1 & 1 & 0 & 1 & 0 & 1 & 1 & 1 & 1 & 1 & \begin{tabular}{l|l}
1 & 1 \\
\end{tabular} & 1 & 0 & 0 & 1 \\
\hline nop & 1 & 1 & 1 & 1 & - & 0 & 1 & 0 & 0 & 0 & 0 & 1 & \begin{tabular}{l|l}
0 & 1 \\
\end{tabular} & 0 & 0 & 0 & 0 \\
\hline ocel & 1 & 0 & 1 & 1 & 1 & 1 & 0 & 0 & 0 & 0 & 0 & 1 & \begin{tabular}{l|l}
1 & 1 \\
\end{tabular} & 0 & 1 & 1 & 0 \\
\hline oton & 0 & 1 & 1 & \begin{tabular}{l|l}
1 & 1 \\
\end{tabular} & 0 & 1 & 0 & 1 & 0 & 1 & 0 & 0 & \begin{tabular}{l|l}
0 & $\mathrm{C}$ \\
\end{tabular} & 0 & 11 & 0 & 0 \\
\hline petaca `s & 1 & 0 & 1 & \begin{tabular}{l|l}
1 & 0 \\
\end{tabular} & 0 & 0 & 0 & 0 & 0 & 1 & 0 & 1 & \begin{tabular}{l|l}
0 & $C$ \\
\end{tabular} & 0 & 1 & 0 & 0 \\
\hline petaca `t & 0 & 0 & 0 & \begin{tabular}{l|l}
0 & 1 \\
\end{tabular} & 0 & 1 & 0 & 0 & 0 & 0 & 0 & 0 & \begin{tabular}{l|l}
0 & 0 \\
\end{tabular} & 0 & 1 & 0 & 0 \\
\hline tam & 1 & 1 & 1 & 1 & 1 & 1 & 0 & 0 & 1 & 0 & 1 & 1 & \begin{tabular}{l|l}
1 & 1 \\
\end{tabular} & 1 & 0 & 0 & 0 \\
\hline zapote 'tree' & & 1 & 1 & \begin{tabular}{l|l|}
1 & 1 \\
\end{tabular} & 1 & 0 & 0 & 1 & 1 & 1 & 1 & & \begin{tabular}{l|l}
0 & $\mathrm{C}$ \\
\end{tabular} & \begin{tabular}{l|l}
0 & 0 \\
\end{tabular} & 0 & 0 & 0 \\
\hline & & & & & & & & & & & & & & & & & \\
\hline
\end{tabular}


Table 2. Generalisation index obtained from the registered Nahuatlisms

\begin{tabular}{|c|c|c|c|}
\hline Countries & $\begin{array}{c}\text { Nahuatlisms } \\
\text { TOTAL }\end{array}$ & $\begin{array}{l}\text { Terms among the } 33 \\
\text { most common terms }\end{array}$ & $\begin{array}{c}\text { Generalisation } \\
\text { index }\end{array}$ \\
\hline Mx & 718 & 28 & 0.0390 \\
\hline ES & 434 & 20 & 0.046 \\
\hline $\mathrm{Ni}$ & 379 & 24 & 0.063 \\
\hline $\mathrm{Gu}$ & 326 & 25 & 0.077 \\
\hline Ho & 518 & 26 & 0.050 \\
\hline $\mathrm{CR}$ & 156 & 16 & 0.103 \\
\hline $\mathrm{Pa}$ & 61 & 20 & 0.328 \\
\hline PR & 30 & 7 & 0.233 \\
\hline DR & 39 & 13 & 0.333 \\
\hline $\mathrm{Cu}$ & 35 & 14 & 0.400 \\
\hline $\mathrm{Ve}$ & 38 & 17 & 0.447 \\
\hline $\mathrm{Co}$ & 32 & 15 & 0.469 \\
\hline $\mathrm{Pe}$ & 40 & 17 & 0.425 \\
\hline $\mathrm{Ar}$ & 24 & 10 & 0.417 \\
\hline Ec & 44 & 17 & 0.386 \\
\hline Py & 7 & 4 & 0.571 \\
\hline Bo & 36 & 15 & 0.417 \\
\hline Ur & 14 & 5 & 0.357 \\
\hline $\mathrm{Ch}$ & 34 & 9 & 0.265 \\
\hline US & 2 & 0 & 0.000 \\
\hline
\end{tabular}

In representing these values (the total number of terms and generalisation index) as axis coordinates, the countries are listed over a highly significant distribution. Those that exhibit a higher number of terms are also those that show the lowest levels of diffusion, i.e., they possess a markedly local character. Meanwhile, countries that exhibite the fewest terms of this origin show much higher generalisation indices, as shown in Figure 2. The correlation between both variables is very high, reaching a Pearson index of -8.34 .

It is worth noting that the data show distinct groups. While Mesoamerican territories present a very low generalisation index, the Caribbean and South American regions have high indices. This means of classifying countries reinforces divisions between countries in the region and clarifies groupings of certain countries such as Panama, which, despite its location in Mesoamerica, can be considered for the purposes of this study as a Caribbean territory. 


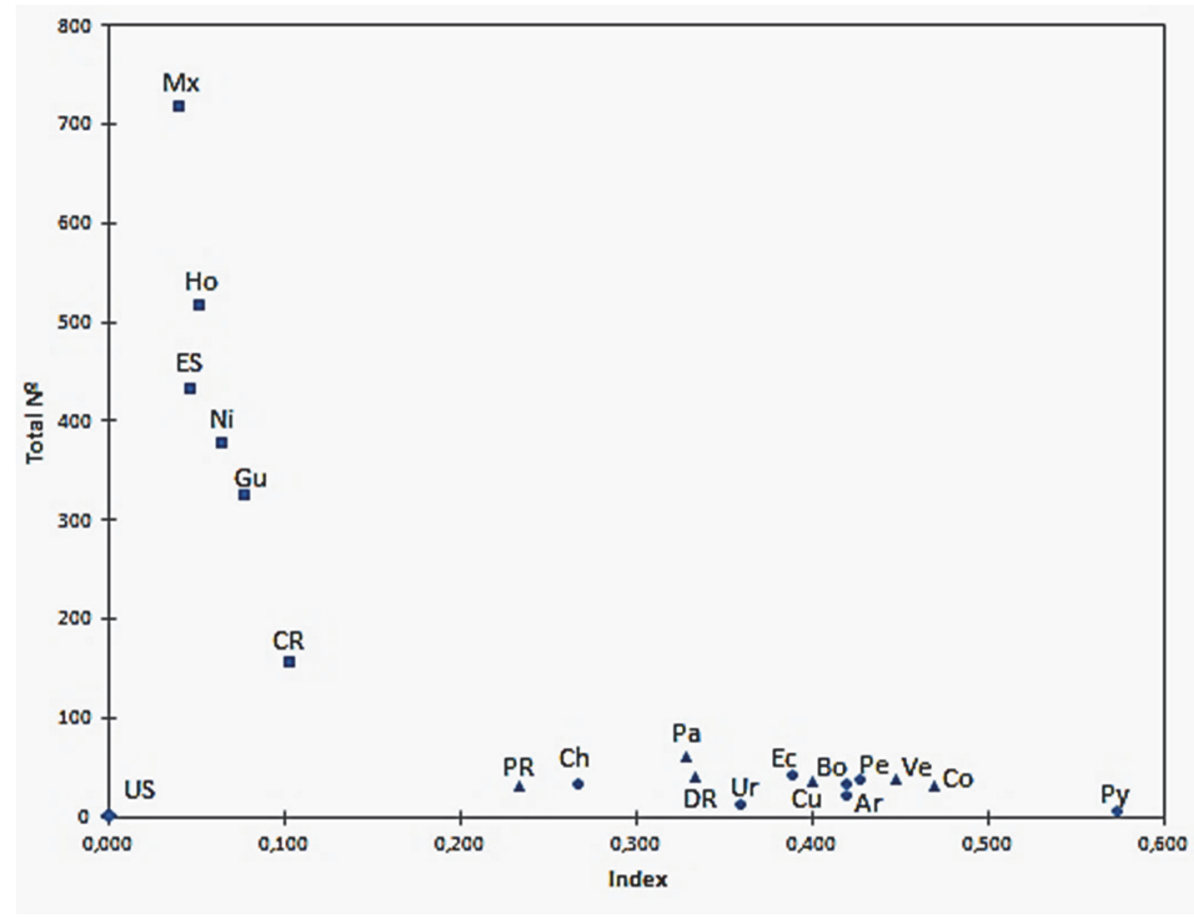

Fig. 2. Nahuatlism trends according to DA data. $=$ Mesoamerica (Cr: Costa Rica; ES: El Salvador; Gu: Guatemala; Ho: Honduras; Mx: México; Ni: Nicaragua); $\mathbf{\Delta =}$ the Caribbean (Cu: Cuba; Co: Colombia; Pa: Panamá; PR: Puerto Rico; DR: Dominican Republic; Ve: Venezuela); $\bullet=$ South America (Ar: Argentina; Bo: Bolivia; Ch: Chile; Ec: Ecuador; Py: Paraguay; Pe: Peru; Ur: Uruguay); = North America (US: United States)

\section{Conclusions}

Our analysis of Nahuatl word diffusion in the dialectal vocabulary of American Spanish leads to the following findings:

i) The dialectal vocabulary of American languages registers nearly three times more words than those found in standard Spanish academic dictionaries (473 cases compared to 1,454$)$. This finding can guide future diachronic and synchronic studies of Nahuatl dialectal vocabularies in the Spanish language. More specifically, words that refer to nature and human or animal traits exhibit the highest levels of diffusion. These results coincide with studies by Mejías (1980), Zamora Munné (2002) and Bravo García and Cáceres Lorenzo (2013).

ii) Quantitative and qualitative analysis of these trends shows that Nahuatlisms (names and meanings) have spread to the Caribbean and South American regions. In the three areas, this diffusion is limited to $2 \%$ of 
the total number of Nahuatlisms. Only 33 words (out of 1,454 Nahuatlisms) represent common dialectal words. This trend exhibits a larger number of coinciding meanings within the Caribbean than within South America. This conclusion does not corroborate findings for the $16^{\text {th }}$ and $17^{\text {th }}$ centuries, thus providing avenues for further diachronic and synchronic examination.

iii) The findings related to regionalisation and the degree of generalisation are in agreement. Regionalisation in Mesoamerica represents a differential element of Nahuatlisms (84.5\% cases). This territorial delimitation demonstrates that countries which incorporate numerous Nahuatlisms exhibit lower levels of standardisation, as they are used only in one region. Trends of double regionalisation can be observed in numerous examples as 1,331 cases are only found in a single region. Among these, the most common Nahuatl words have resulted from lexical levelling, although they may compete with other Indoamerican words in the Caribbean and South American regions. This finding denotes high degrees of generalisation in these countries and reveals that Nahuatlisms in the Caribbean and South America, though present, are not common.

\section{References}

Primary sources

DA. 2010. Asociación de Academias de la Lengua Española. Diccionario de americanismos [Dictionary of Americanisms]. Madrid: Santillana.

DRAE. 2014. Real Academia Española. Diccionario de la lengua española [Dictionary of the Spanish Language], (23 ed.). Madrid: Espasa.

\section{Secondary sources}

Alvar Ezquerra, Manuel. 1986. Los regionalismos en los diccionarios y vocabularios regionales. In M. Alvar (coord.), Lenguas peninsulares y proyección hispánica, 175-197. Madrid: Fundación Friedrich Ebert.

Ávila, Raúl. 2004. ¿El fin de los diccionarios diferenciales?, ¿el principio de los diccionarios integrales? [The end of differential dictionaries? The beginning of comprehensive dictionaries?]. Revista de lexicografia 10: 7-20.

Bastardín Candón, Teresa. 2013. Vocabulario indígena en la Historia de fray Bernardino de Sahagún [Indigenous vocabulary in the history of Fray Bernardino de Sahagun]. Frankfurt am Main: Peter Lang.

Bravo García, Eva / María Teresa Cáceres Lorenzo. 2013. El léxico cotidiano en América a Través de las Relaciones Geográficas de Indias (Tierra Firme y América del Sur, s. XVI) [Everyday lexicon in America Through the Geographical Relations of the Indies (Mainland and South America, s. XVI)]. Bern: Peter Lang. 
Cáceres-Lorenzo, María-Teresa. 2013. Indoamericanismos de uso general en documentos españoles americanos (1502-1560): propuesta de clasificación y resultados. Bulletin of Spanish Studies 90: 1079-1090.

Charles, John. 2007. 'More Ladino than Necessary': Indigenous Litigants and the Language Policy Debate in Mid-Colonial Peru. Colonial Latin American Review 16 (1): 23-47.

Company, Concepción. 2003. ¿Qué es un cambio lingüístico? [What is a language change?]. In F. Colombo \& A. Soler (eds.), Normatividad y cambio lingüístico [Norms and language change], 13-32. México: Universidad Nacional Autónoma de México.

Covarrubias, Sebastián de. 2006 [1611]. Tesoro de la lengua castellana o española [Treasury of the Castilian or Spanish language]. Edición integral e ilustrada de Ignacio Arellano y Rafael Zafra. Madrid: Iberoamericana-Vervuert.

Enguita Utrilla, José Ma . 2004. Para la historia de los americanismos léxicos [History for lexical Americanisms]. Frankfurt am Main: Peter Lang.

Enguita Utrilla, José Ma . 2009. Contacto de lenguas en la Relación de Cristóbal de Molina (BNM, ms. 3169) [Language contact in the Relation of Cristobal de Molina (BNM, ms. 3169)]. In Montserrat Veyrat \& Enrique Serra (eds.), La Lingüistica como reto epistemológico y como acción social. Estudios dedicados al Profesor Ángel López García con ocasión de su sexagésimo aniversario, 317328, 2 vols. Madrid: Ed. Arco Libros.

Frago Gracia, Juan Antonio. 1999. Historia del español de América [History of Spanish America]. Madrid: Gredos.

Frago Gracia, Juan Antonio. 2003. Variación dialectal y sociocultural en la documentación indiana del siglo XVI [Dialectal variation in sociocultural and "indiana" documentation of the sixteenth century]. In El español de América 1992, 145-166. Madrid: CSIC, Anejos de la Revista de Filología Española.

Goodwin, Robert T. C. 2007. 'De lo que sucedió a los demás que entraron en las Indias': Alvar Núñez Cabeza de Vaca and the Other Survivors of Pánfilo Narváez's Expedition. Bulletin of Spanish Studies: Hispanic Studies and Researches on Spain, Portugal and Latin America 84 (2). 147-173.

Hernández, Esther. 1996. Vocabulario en lengua castellana y mexicana de fray Alonso de Molina [Vocabulary Spanish language and Mexican Fray Alonso de Molina] Madrid: Consejo Superior de Investigaciones Científicas, Biblioteca de Filología Hispánica.

Klor de Alva, Jorge.1989. Language, Politics and Translation [Language, Politics and Translation]. In Rosanna Warren (ed.), Colonial Discourse and Classical Nahuatl in New Spain, 143-162. Boston: Northeastern University Press.

León Portilla, Miguel. 1999. Bernardino de Sahagún. Pionero de la antropología [Bernardino de Sahagun. Pioneer anthropology]. México, D.F.: UNAM y El Colegio de México.

Lockhart, James. 1999. Los nahuas después de la Conquista. Historia social y cultural de la población indígena del México central, siglos XVI-XVIII [Nahuas after the Conquest. Social and cultural history of the indigenous population of central Mexico, XVI-XVIII centuries]. México: Fondo de Cultura Económica. 
Looze, Laurence. 2005. Transatlantic Textuality: The Encounter between Spanish and Indigenous Textuality in the Pages of the Sixteenth-Century mestizo codices of Mexico. Mediterranean Studies 14: 106-124.

Lope Blanch, Juan M. 1993. Caracterización del español mexicano [Characterisation of Mexican Spanish]. In Ensayos sobre el español de América, 119-136. México: UNAM.

Lope Blanch, Juan M. 1998. Los nahuatlismos del Diccionario Académico Homenaje al profesor Ambrosio Rabanales [The Nahuatl words of the Academic Dictionary. Tribute to Professor Ambrosio Rabanales]. Boletín de Filología Chilena XXXVII. 669-680.

Lope Blanch, Juan M. 1999. Americanismos en el Vocabulario de Fray Alonso de Molina [Americanisms in the vocabulary of Fray Alonso de Molina]. In Amparo Morales \& $\mathrm{M}^{\mathrm{a}}$ Tránsito Vaquero de Ramírez (eds.), Estudios de lingüística hispánica: Homenaje a María Vaquero, 335-347. Puerto Rico: Univ. de Puerto Rico.

López Austin, Alfredo. 1974. The Research Method of Fray Bernardino de Sahagún: the Questionnaires. In Munro S. Edmonson, Sixteenth Century Mexico, the Work of Sahagún, 111-149. Albuquerque: University of New Mexico Press.

López Morales, Humberto. 1974. Indigenismos en los textos cronísticos de Puerto Rico: índices de frecuencia y densidad [Indigenous in the Chronicles in Puerto Rico. Frequency and density índices]. In Marcos A. Morínigo (ed.), Estudios filológicos y lingüísticos. Homenaje a Ángel Rosenblat en sus 70 años, 327-346. Caracas: Instituto Pedagógico.

Mejías, Hugo. 1980. Préstamos de lenguas indígenas en el español americano del siglo XVII [Loans of indigenous languages in the seventeenth-century Spanish American]. México: UNAM.

Oesterreicher, Wulf. 2002. El español, lengua pluricéntrica: perspectivas y límites de una autoafirmación lingüística nacional en Hispanoamérica. El caso mexicano. [The Spanish, pluricentric language. Prospects and limits of a linguistic national self-assertion in Hispanic America. The Mexican case]. Lexis. Revista de Lingüistica y Literatura 26: 275-304.

Pizzigoni, Caterina. 2012. Conclusion: A Language across Space, Time, and Ethnicity. Ethnohistory 59 (4): 785-790.

Ricard, Robert. 2001. La conquista espiritual de México [The Spiritual conquest of Mexico]. México: Fondo de Cultura Económica.

Rodríguez Reboiras, Fernando. 2010. El cuidado y curiosidad de los franciscanos de Nueva España por las lenguas indígenas y su contexto político [The Caring and Curiosity of the Franciscans about the indigenous languages in New Spain and its political context]. In Wulf Oesterreich \& Roland Schmidt-Riese (eds.), Esplendores y miserias de la evangelización de América. Antecedentes europeos $y$ alteridad indígena, 301-331. Madrid-Frankfurt: Iberoamericana-Vervuert Verlag.

Sánchez-Albornoz, Nicolás. 2001. De las lenguas amerindias al castellano. Ley o interacción en el período colonial [From the Castilian Amerindian languages. Law or interaction in the colonial period]. Colonial Latin American Review 10 (1): 49-67. 
Sánchez Méndez, Juan P. 2010. Los presupuestos ideológicos, culturales, lingüísticos y religiosos de la evangelización americana. A propósito de Fray Juan de Zumárraga [Ideological, cultural, linguistic and religious evangelisation of American budgets. Speaking of Fray Juan de Zumarraga]. In Wulf Oesterreich \& Roland Schmidt-Riese (eds.), Esplendores y miserias de la evangelización de América. Antecedentes europeos y alteridad indígena, 3-24. Berlín/Nueva York: de Gruyter.

Schäffner, Christina. 2012. Intercultural intertextuality as a translation phenomenon, Perspectives: Studies in Translatology 20 (3): 345-364.

Schwaller, Robert. 2012. The Importance of Mestizos and Mulatos as Bilingual Intermediaries in Sixteenth-Century New Spain. Ethnohistory 59 (4): 713-738.

Solano, Francisco. 1992. Documentos sobre política lingüistica en Hispanoamérica, 1492-1800 [Documents about language policy in Hispanic America]. Madrid: CSIC.

Tabernero Sala, Cristina. 2011. Indigenismos y nivelación léxica del español americano en los siglos XVI y XVII [Indigenisms and lexical leveling in American Spanish in the sixteenth and seventeenth centuries]. Alpha 33: 215-231.

Terborg, Roland, Laura García Landa \& Pauline Moore. 2006. The Language Situation in Mexico. Current Issues in Language Planning 7 (4): 415-518.

Zamora Munné, Juan Clemente. 2002. Indigenismos en la lengua de los conquistadores [Indigenisms in the language of the conquerors]. Hesperia. Anuario de Filología Hispánica V: 195-209.

Zavala, Silvio. 1996. Poder y lenguaje desde el siglo XVI [Power and language since the sixteenth century]. México: El Colegio de México.

María-Teresa Cáceres-Lorenzo • University of Las Palmas de Gran Canaria • mteresa.caceres@ulpgc.es 